\title{
Phylogenetic diversity, polyamine pattern and DNA base composition of members of the order Planctomycetales
}

\author{
Ulrich Griepenburg, ${ }^{1}$ Naomi Ward-Rainey, ${ }^{2}+$ Sahera Mohamed, ${ }^{1}$ \\ Heinz Schlesner, ${ }^{3}$ Helga Marxsen, ${ }^{3}$ Fred A. Rainey, ${ }^{2}+$ Erko Stackebrandt ${ }^{2}$ \\ and Georg Auling ${ }^{1}$
}

Author for correspondence: Heinz Schlesner. Tel: +49 431880 4332. Fax: +494318802194. e-mail: hschlesner@ifam.uni-kiel.de

1 Institut für Mikrobiologie der Universităt Hannover, Schneiderberg 50, D-30167 Hannover, Germany

2 DSMZ - Deutsche Sammlung von Mikroorganismen und Zellkulturen $\mathrm{GmbH}$, Mascheroder Weg 1b, D-38124 Braunschweig, Germany

3 Institut für Allgemeine Mikrobiologie der Universität Kiel, Am Botanischen Garten 1-9 D-24118 Kiel, Germany

\begin{abstract}
The 16S rDNA sequences of 20 novel isolates of members of the order Planctomycetales were compared to those of the type strains of described planctomycete species and 22 planctomycete isolates for which the $16 \mathrm{~S}$ rDNA sequences had been previously determined. The novel isolates could be assigned to several phylogenetically broad groups, four of which are defined by the genera Gemmata, Isosphaera, Planctomyces and Pirellula. To evaluate polyamines as a chemotaxonomic marker within this order, the polyamine pool was determined for six planctomycete reference species and for $\mathbf{2 0}$ planctomycete isolates. All analysed members of the order Planctomycetales contained significant amounts of polyamines. sym-Homospermidine (HSPD) is present in all strains except Planctomyces limnophilus and related strains, which had high amounts of putrescine (PUT) as the dominant polyamine component. The distribution of PUT, HSPD and spermidine reflects the phylogenetic diversity within the Planctomycetales as closely related representatives of the phylogenetic groups defined by described species and novel isolates exhibit similar polyamine patterns. Determination of the DNA base composition revealed $\mathrm{G}+\mathrm{C}$ contents of $>60 \mathrm{~mol} \%$ for members of Gemmata and Isosphaera whereas, except for two isolates, strains which are phylogenetically associated with Planctomyces and Pirellula had G+C contents of $51-57 \mathrm{~mol} \%$.
\end{abstract}

Keywords: Planctomycetales, 16S rDNA sequence analyses, chemotaxonomy, polyamines, DNA base composition

\section{INTRODUCTION}

The order Planctomycetales represents one of the major lines of descent of the domain Bacteria as defined on the basis of $16 \mathrm{~S}$ rRNA sequence analysis (Woese, 1987; Ward et al., 1995). Members of this order differ in several characteristics from other bacterial taxa: (i) they multiply by forming buds directly from the spherical, ovoid or pear-shaped

†Present address: Department of Biological Sciences, Louisiana State University, Baton Rouge, LA 70809, USA.

Abbreviations: ASW, artificial seawater; $C A D$, cadaverine; DAP, diaminopropane; HSPD, sym-homospermidine; PUT, putrescine; SPD, spermidine; SPM, spermine.

The GenBank/EMBL/DDBJ accession numbers for the sequences reported in this paper are AJ231168-AJ231195. mother cell; (ii) the cell wall is stabilized by a proteinaceous layer rather than a peptidoglycan layer (König et al., 1984; Liesack et al., 1986); (iii) the cell surface is scattered with 'crateriform structures' (Schlesner \& Stackebrandt, 1986; Staley et al., 1992) which, outside the planctomycetes proper, has only been reported for Porphyrobacter neustonensis (Fuerst et al., 1993); (iv) the 5S rRNA contains only 109-111 bases (Bomar et al., 1988); and (v) certain idiosyncrasies have been detected at the genome level (Liesack \& Stackebrandt, 1989; Ward-Rainey et al., 1996).

The order Planctomycetales contains the family Planctomycetaceae (Schlesner \& Stackebrandt, 1986) in which four genera have been described mainly on a morphological basis. Members of Planctomyces are 
Table 1. Strains investigated in this study, their culture conditions and $G+C$ content (mol \%) of their rRNA genes

Strains are arranged according to their phylogenetic position. Unless otherwise indicated, all strains were isolated in northern Germany. See Methods for growth media references.

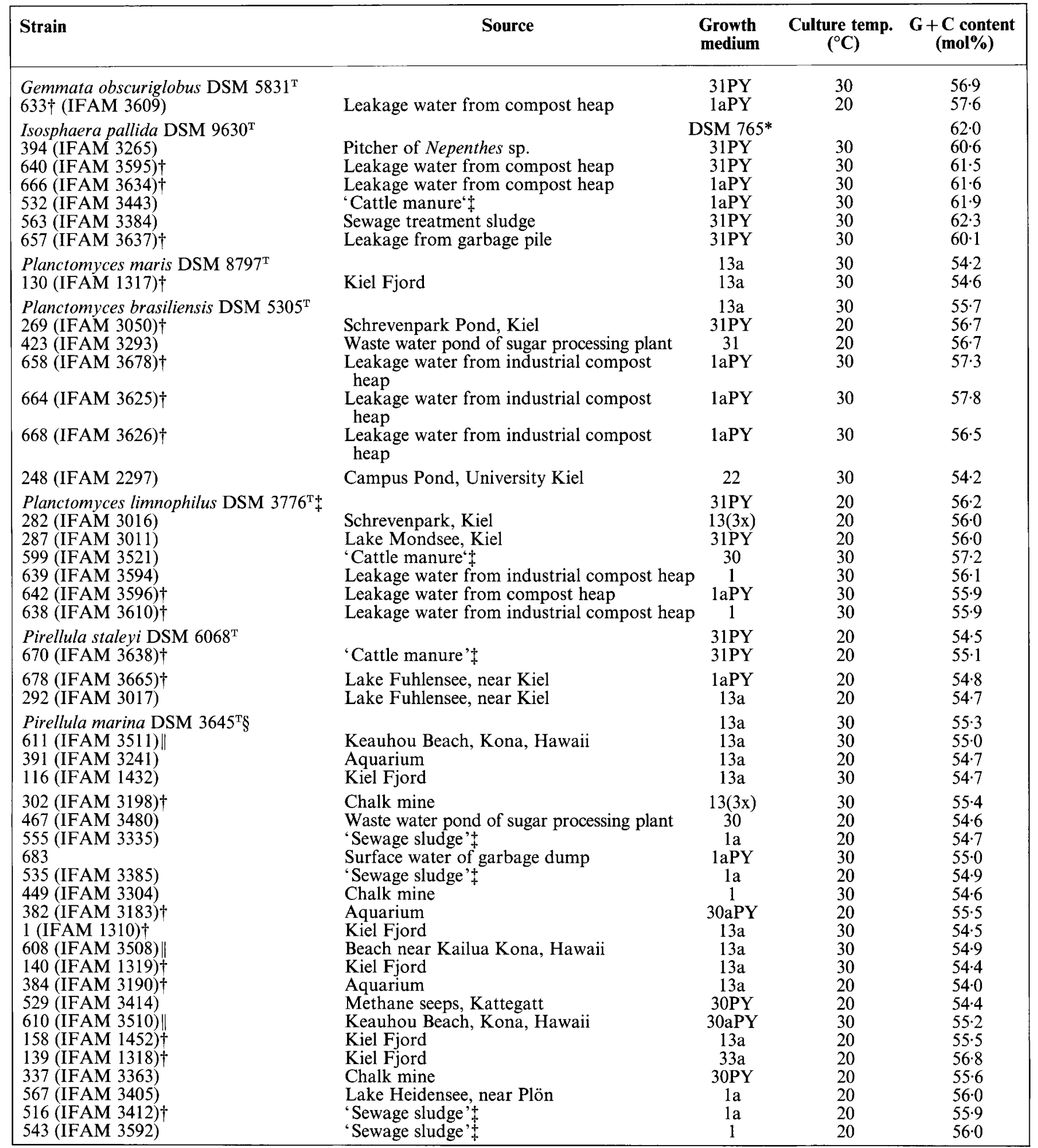

* See DSMZ Catalogue of Strains, 6th edn, 1998.

$\dagger$ 16S rDNA sequences have been published by Ward et al. (1995).

\$ Cattle manure' and 'sewage sludge' are pilot projects for converting manure and sludge to fertilizer. §16S rDNA sequences have been published by Liesack et al. (1992).

$\|$ Isolated and kindly provided by J. T. Staley, Seattle, WA, USA. 
characterized by a non-cellular stalk terminating in a holdfast opposite the reproductive cell pole. Cells of members of Pirellula excrete holdfast substance directly from the cell pole opposite the reproductive pole. In both genera, rosette formation is common. The daughter cells are non-motile or possess a single flagellum (Schlesner \& Hirsch, 1984; Staley et al., 1992) whereas the swarmer cells of Gemmata obscuriglobus (the only described species of the genus) have bundles of flagella (Franzmann \& Skerman, 1984). Isosphaera pallida (the only described species of the genus) has spherical cells which form gliding filaments in which daughter cells are formed within the chain of cells (Giovannoni et al., 1987).

Ten planctomycete species are currently described, of which only seven have been cultured. Considering the large phylogenetic depth separating these cultured strains (Liesack et al., 1992), it is likely that the majority of planctomycete strains have not yet been recovered from the environment. The recent development of selective media containing $\mathrm{N}$-acetylglucosamine as carbon and nitrogen source as well as antibiotics, i.e. ampicillin and cycloheximide, added for suppression of growth of other micro-organisms, has allowed the isolation of numerous strains from diverse aquatic habitats with a wide range of salinity (fresh to hypersaline water), $\mathrm{pH}(4 \cdot 2-11 \cdot 6)$ and pollution (oligotrophic vs eutrophic) (Schlesner, 1994). Phylogenetic studies on a large number of these strains have expanded the phylogenetic structure at the interand intrageneric level (Ward et al., 1995). Whether or not the emerging structure can be used to describe novel taxa depends upon the availability of phenotypic properties, such as phospholipids and fatty acids (Sittig \& Schlesner, 1993), as well as physiological properties.

In this study, the 16S rDNA sequences were determined for 20 novel planctomycete isolates, and the DNA base composition and polyamine patterns, the latter of which have been found useful in the characterization of methanogenic archaea (Scherer \& Kneifel, 1983), members of the Vibrionaceae (Yamamoto et al., 1983) and the Proteobacteria (Busse \& Auling, 1988; Auling, 1992) and certain Grampositive bacteria (Altenburger et al., 1997), were analysed.

\section{METHODS}

Bacterial strains. Pirellula marina IFAM $1313^{\mathrm{T}}(=\mathrm{DSM}$ $3645^{\mathrm{T}}$ ), Pirellula staleyi IFAM $1189^{\mathrm{T}}$ (=DSM 6068 ${ }^{\mathrm{T}}$ ), Planctomyces limnophilus IFAM $1008^{\mathrm{T}}$ (=DSM $3776^{\mathrm{T}}$ ), Pirellula brasiliensis IFAM $1448^{\mathrm{T}}\left(=\mathrm{DSM} 5305^{\mathrm{T}}\right)$ and Pirellula maris IFAM $1190^{\mathrm{T}}$ (=DSM $8797^{\mathrm{T}}$ ) were taken from the IFAM (Institut für Allgemeine Mikrobiologie, University of Kiel, Germany) departmental culture collection. G. obscuriglobus DSM 5831 ${ }^{\mathrm{T}}$ (=UQM 2246 ${ }^{\mathrm{T}}$ ) was obtained from the DSMZ (Deutsche Sammlung von Mikroorganismen und Zellkulturen, Braunschweig, Germany). Planctomycete strains originated from various aquatic habitats (Table 1) and were obtained from IFAM. Described planctomycete species were obtained from the DSMZ for
16S rDNA analysis. Methods of sampling, enrichment and isolation have been recently described (Schlesner, 1994).

Media. Media differing in carbon and nitrogen sources and in salinity were as described previously (Schlesner, 1986, 1994). Additionally, M33a was used, which consisted of: gelatin, $2.0 \mathrm{~g}$; yeast extract, $0.25 \mathrm{~g}$; glucose, $0.25 \mathrm{~g}$; Hutner's basal salts medium (HBM; Cohen-Bazire et al., 1957), $20 \mathrm{ml}$; vitamin solution no. 6 (Staley, 1968), $10 \mathrm{ml} ; 100 \mathrm{mM}$ Tris $/ \mathrm{HCl}$ buffer (pH 7.5), $50 \mathrm{ml}$; artificial seawater (ASW; Lyman \& Fleming, 1940), $500 \mathrm{ml}$; double-distilled water, $420 \mathrm{ml}$; and agar, $18 \mathrm{~g}$.

Cultivation of bacteria. Cell material for DNA base composition determination was grown on heavily inoculated Petri dishes with the appropriate solid medium (Table 1). Cells were harvested with a rubber spatula, lyophilized and stored at $-20^{\circ} \mathrm{C}$. For polyamine analysis, strains were grown in liquid cultures. Cells were harvested near the end of the exponential growth phase by centrifugation, washed with distilled water, lyophilized and stored at $-20^{\circ} \mathrm{C}$.

Determination of DNA base ratio. DNA was extracted from $0.02 \mathrm{~g}$ freeze-dried cells in $1.5 \mathrm{ml}$ Eppendorf reaction caps following the procedure of Marmur (1961). Analysis of the $\mathrm{G}+\mathrm{C}$ content of DNA by HPLC was performed according to Mesbah et al. (1989).

Polyamine analysis. The polyamines were extracted and analysed by gradient HPLC and fluorescence detection according to Busse \& Auling (1988).

165 rDNA sequence analysis. The extraction of genomic DNA and the amplification of 16S rDNA were performed as described previously (Rainey et al., 1996a). Cloning of PCR products was performed using the pCR-Script kit (Stratagene) as described previously (Rainey et al., 1996b). The PCR products were purified by using the Prep-A-Gene kit (Bio-Rad) as described by the manufacturer. The DyeDeoxy Terminator Cycle Sequencing kit (Applied Biosystems) was used to directly sequence the PCR products as described by the manufacturer. The sequence reactions were electrophoresed on the Applied Biosystems 373A DNA Sequencer. Accession numbers of isolates published previously (Ward et al., 1995) are X81938-X81960.

Data analyses. The sequences were aligned manually against available sequences for members of the order Planctomycetales. Pairwise evolutionary distances were computed by using the correction of Jukes \& Cantor (1969). Parsimony analysis, maximum-likelihood and neighbour-joining were carried out using the programs of the PHYLIP package (Felsenstein, 1993). The 16S rDNA sequence of Chlamydia psittaci (EMBL accession no. M13769) was used to root the tree. Bootstrap analyses was used to determine the statistical significance of the branching patterns.

Nucleotide accession numbers. Accession numbers for sequences are as follows: AJ231168, strain 608; AJ231169, strain 529; AJ231170, strain 610; AJ231171, strain 337; AJ231172, strain 567; AJ231173, strain 543; AJ231174, strain 467; AJ231175, strain 683; AJ231176, strain 535; AJ231177, strain 449; AJ231178, strain 555; AJ231179, strain 611; AJ231180, strain 391; AJ231181, strain 116; AJ231182, strain 292; AJ231183, Pirellula staleyi DSM 6068 ; AJ231184, Planctomyces maris DSM $8797^{\mathrm{T}}$; AJ231185, strain 423; AJ231186, strain 248; AJ231187, strain 287; AJ231188, strain 282; AJ231189, strain 599; AJ231190, Planctomyces brasiliensis DSM 5305 ${ }^{\mathrm{T}}$; AJ231191, G. obscuriglobus DSM 5831 ${ }^{\mathrm{T}}$; AJ231192, strain 394; 
AJ231193, strain 563; AJ231194, strain 532; AJ231195, $I$. pallida DSM $9630^{\mathrm{T}}$.

\section{RESULTS AND DISCUSSION}

\section{Phylogenetic analysis of isolates}

Twenty novel planctomycete isolates from aquatic habitats in the state of Schleswig-Holstein, Germany (Schlesner, 1994) were analysed with respect to the primary structure of the 16S rRNA gene. Planctomyces brasiliensis DSM $5305^{\mathrm{T}}$, which was not investigated in a previous phylogenetic study of members of the four planctomycete genera (Liesack et al., 1992), was also included in this study. The $16 \mathrm{~S}$ rDNA sequence of Planctomyces maris DSM $8797^{\mathrm{T}}$ was redetermined, because the available sequence (EMBL accession no. $\mathrm{X} 62910$ ) was not complete. New sequence data were obtained for $G$. obscuriglobus DSM $5831^{\mathrm{T}}$, I. pallida DSM $9630^{\mathrm{T}}$ and Pirellula staleyi DSM $6068^{\mathrm{T}}$ because the available sequences (X56305 and X54522 for $G$. obscuriglobus, X64372 for I. pallida, no deposited $16 \mathrm{~S}$ rDNA sequence for Pirellula staleyi) contained some ambiguous nucleotide positions. The almost complete sequences, covering regions from position 40 through position 1519 (according to Escherichia coli nomenclature; Brosius et al., 1978) were aligned to the homologous sequences of described planctomycete species (Liesack et al., 1992) and isolates that have been investigated recently (Ward et al., 1995). Direct sequencing of the $5^{\prime}$ region of the 16S rDNA PCR products of Planctomyces brasiliensis, Planctomyces maris and G. obscuriglobus generated sequence data that were not readable. The 16S rDNA PCR products from these strains were subsequently cloned and the clones were sequenced in order to determine whether the mixed sequence was due to sequence heterogeneity contained within multiple $r r n$ operons in these strains. Sequence analysis of ten cloned 16S rDNA genes from each strain revealed only a single sequence for each strain. This makes it unlikely that the unreadable sequence data obtained by direct sequencing of the $16 \mathrm{~S}$ rDNA PCR products from these strains was due to $16 \mathrm{~S}$ rDNA sequence heterogeneity.

The addition of sequences of the novel isolates to the database did not significantly change the topology of the previously published phylogenetic dendrogram based on the analysis of 32 planctomycete strains (Ward et al., 1995). Some of the novel strains clustered with strains previously affiliated to I. pallida (strains 394, 532 and 563), Planctomyces limnophilus (strains 282, 287 and, more distantly, 599), as well as Pirellula marina (strains 116, 391 and 611). Other strains formed novel discrete clusters with previously analysed strains. The range of intra- and intercluster 16S rDNA similarity values (not shown) and the sequence idiosyncrasies, described to characterize certain species of the four planctomycete genera (Ward et al., 1995), did not change by the inclusion of the novel isolates. Members of the Isosphaera cluster were characterized by a $\mathrm{G}+\mathrm{C}$ content $(\mathrm{mol} \%)$ of the rRNA gene that was

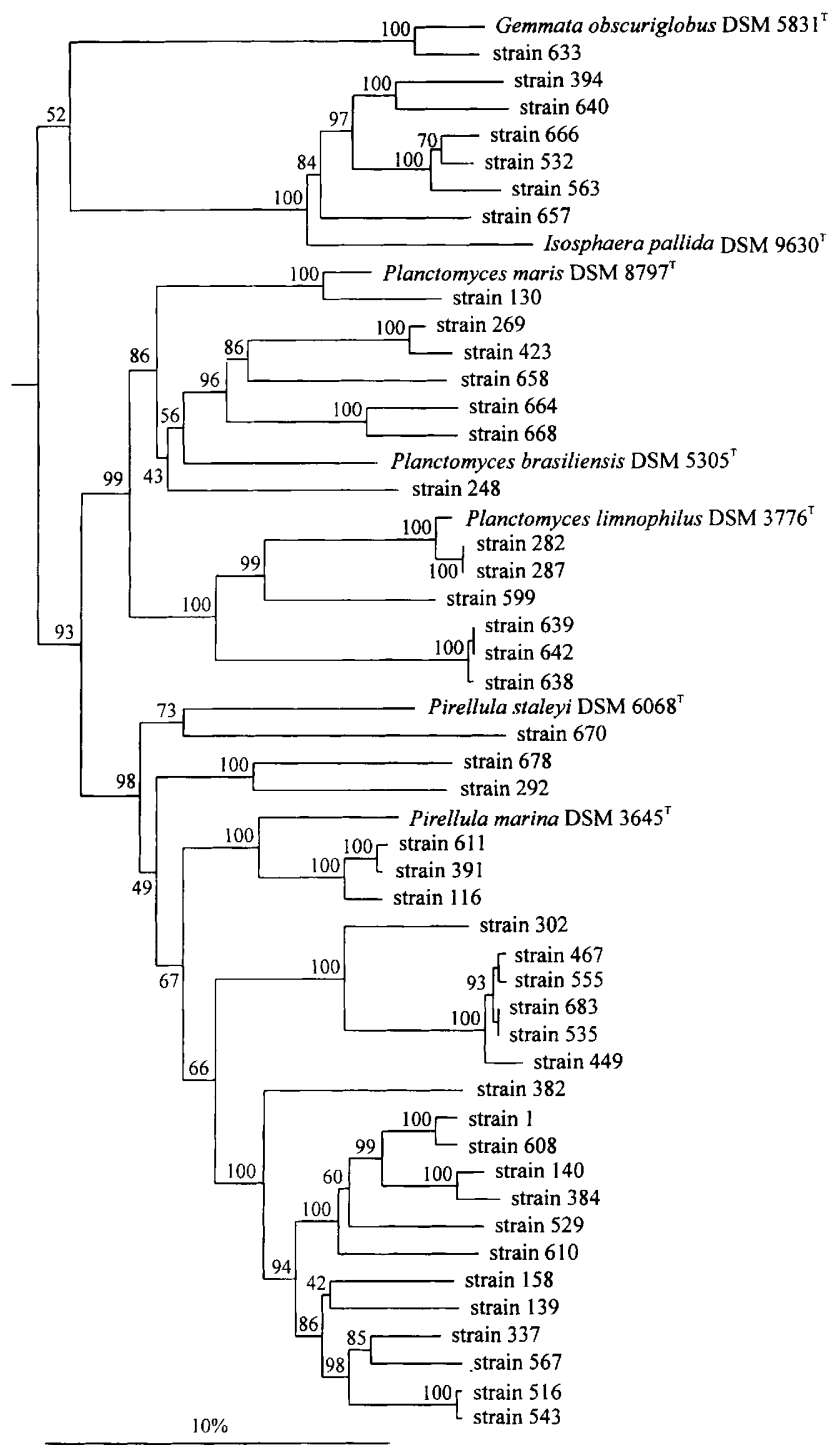

Fig. 1. $16 \mathrm{~S}$ rDNA dendrogram indicating the phylogenetic position between described species of the family Planctomycetaceae and isolates from various sites in northern Germany and from Hawaii. The root was determined by using the 16S rDNA sequence of Chlamydia psittaci as an outgroup reference. The dendrogram was generated by the neighbourjoining algorithm (Felsenstein, 1993). Bar, 10\% sequence divergence. Numbers refer to bootstrap values.

about 3-4\% higher than those found in members of the genera Gemmata, Planctomyces, Pirellula and the novel associated rDNA clusters (Table 1).

The emerging phylogenetic clusters are, in most cases, as unrelated among themselves as they are related to the type strains of described species, i.e. in the order of only $85-88 \% 16 \mathrm{~S}$ rDNA sequence similarities. Even some of the intracluster similarities are as low as $87-92 \%$, such as strain 599 and Planctomyces limnophilus, strains 678 and 292, the three major clusters of the Pirellula marina branch, and certain strains that cluster with I. pallida (Fig. 1). When 
Table 2. Effect of increasing salinity and nutrient concentration on the polyamine pool [ $\mu \mathrm{mol}$ (g dry weight) ${ }^{-1}$ ] in Planctomyces limnophilus DSM $3776^{\top}$ and strain 1

\begin{tabular}{|c|c|c|c|c|c|}
\hline Strain & Growth condition & PUT & CAD & SPD & HSPD \\
\hline \multirow[t]{6}{*}{ Strain 1} & $13\left(1 / 4 \mathrm{ASW} ; \mathrm{S}=8 \cdot 5 \%{ }^{*}\right)^{*}$ & $19 \cdot 5$ & $15 \cdot 3$ & & $19 \cdot 6$ \\
\hline & 13a $(1 / 2 \mathrm{ASW} ; \mathrm{S}=17 \%)^{*}$ & $13 \cdot 9$ & $7 \cdot 7$ & & $11 \cdot 1$ \\
\hline & $13 \mathrm{~b}\left(\mathrm{ASW} ; \mathrm{S}=34 \%{ }^{*}\right)^{*}$ & $0 \cdot 8$ & 0 & & $2 \cdot 7$ \\
\hline & 13 & $19 \cdot 5$ & $15 \cdot 3$ & & $19 \cdot 6$ \\
\hline & $13(3 x) \dagger$ & $21 \cdot 3$ & $17 \cdot 2$ & & $21 \cdot 8$ \\
\hline & $13(5 x) \dagger$ & $19 \cdot 8$ & $16 \cdot 0$ & & $17 \cdot 4$ \\
\hline Planctomyces limnophilus & $31 \mathrm{PY}$ & $67 \cdot 7$ & & $5 \cdot 3$ & \\
\hline \multirow[t]{2}{*}{ DSM $3776^{\mathrm{T}}$} & $31 \mathrm{PY}(1 / 4 \mathrm{x}) \ddagger$ & $78 \cdot 3$ & & $2 \cdot 0$ & \\
\hline & $31 \mathrm{PY}(1 / 2 \mathrm{x})_{\ddagger}^{\dagger}$ & 71.9 & & $5 \cdot 4$ & \\
\hline
\end{tabular}

* Medium 13 made up with quarter-strength (1/4ASW), half-strength $(1 / 2 \mathrm{ASW})$ or full-strength ASW; S, salinity.

$\dagger$ Medium 13 made up with threefold (3X) or fivefold (5X) concentration of peptone, yeast extract and glucose.

$\ddagger$ Medium 31PY made up with quarter-strength $(1 / 4 \mathrm{X})$ or half-strength $(1 / 2 \mathrm{X})$ concentration of $N$ acetylglucosamine, peptone and yeast extract.

maximum-likelihood, neighbour-joining and parsimony analysis methods were applied to the same data-set used to produce Fig. 1, only some minor rearrangements of branching points within strain clusters were found (data not shown). Hence, from a phylogenetic point, many of the novel isolates investigated previously (Ward et al., 1995) and in this study represent novel species which cannot be described because of the lack of phenotypic and chemotaxonomic properties. To broaden the basis for future taxonomic description the type strains of described species and representative strains of some of the novel clusters were subjected to analysis of the polyamine pattern and DNA G $+\mathrm{C}$ content.

\section{Polyamine analysis}

The intended use of polyamines as biomarkers required examination of the influence of growth conditions on the composition of polyamines, for which Planctomyces limnophilus DSM $3776^{\mathrm{T}}$ and strain 1 were selected. Since initial studies revealed that aged planctomycete cultures have a low polyamine content, the data presented here were from exponentially growing cultures. The polyamine pattern was not significantly influenced by diluting or enriching the organic compounds in the medium (Table 2) or simulating oligotrophic and eutrophic conditions, respectively. However, the polyamine pool of strain 1 was affected dramatically by modifying the salinity of the growth medium in that the pool of total polyamines was reduced with increased concentration of artificial sea water. A similar effect has been reported to occur in Escherichia coli (Munro et al., 1972), strains of Vibrio (Yamamoto et al., 1986) and Deleya marina (Auling et al., 1991).
To allow comparison of data obtained, the majority of strains were grown on media 31PY or 13a (Table 1) which permitted reasonable growth for investigation of polyamines. All strains contained significant amounts of polyamines; in general, the pattern was composed of two or more compounds (Table 3). The concentrations of the polyamine pools in the Planctomycetales were comparable to those reported for other Gram-negative bacterial taxa (Busse \& Auling, 1988; Hamana \& Matsuzaki, 1993). Major compounds were sym-homospermidine (HSPD), putrescine (PUT) and spermidine (SPD). Cadaverine (CAD), diaminopropane (DAP) and spermine (SPM) were found as minor compounds only in a few strains.

The qualitative distribution of the polyamine patterns is by and large consistent with the phylogenetic relatedness of closely related strains. The exception is strain 1, which shows significant levels of PUT and CAT that are almost absent in the related strains 608 and 140. At present, there is no explanation for this discrepancy. Except for Planctomyces limnophilus and the related strains 282 and 287, HSPD was present in all peptidoglycan-free budding bacteria (Table 3 ) and was the only major component in strains of $G$. obscuriglobus, I. pallida and related strains, as well as in the marine planctomycetes Planctomyces maris, the halotolerant Planctomyces brasiliensis and strain 130; however, as compared to the other members of the order Planctomycetales, these marine strains contained rather low amounts of HSPD. The freshwater planctomycetes possessed PUT as the main compound, sometimes in extremely high amounts, as well as significant amounts of SPD. High amounts of PUT, together with HSPD characterized strains of the strain 269 cluster; Planctomyces limnophilus and related 
Table 3. Polyamine $\left.[\mu \mathrm{mol} \text { ( } \mathrm{g} \text { dry weight })^{-1}\right]$ pattern and DNA base ratio of budding peptidoglycan-free isolates and reference species belonging to the order Planctomycetales

\begin{tabular}{|c|c|c|c|c|c|c|c|}
\hline Strain & DAP & PUT & CAD & SPD & HSPD & SPM & $\mathbf{G}+\mathbf{C}(\mathbf{m o l} \%)$ \\
\hline Gemmata obscuriglobus DSM $5831^{\mathrm{T}}$ & & & & & 35.2 & & $64^{*}$ \\
\hline 633 & & 1.0 & $\mathrm{t}$ & & $85 \cdot 0$ & & 70 \\
\hline Isosphaera pallida DSM $9630^{\mathrm{T}}$ & & & & & & & $62^{*}$ \\
\hline 666 & & 1.0 & & & $80 \cdot 1$ & & 72 \\
\hline 532 & & & & & $12 \cdot 9$ & & 70 \\
\hline Planctomyces maris DSM $8797^{\mathrm{T}}$ & & $\mathrm{t}$ & & & $5 \cdot 8$ & & 51 \\
\hline 130 & & & & & $1 \cdot 1$ & & 53 \\
\hline Planctomyces brasiliensis DSM 5305 & & & & $2 \cdot 7$ & $7 \cdot 1$ & & 56 \\
\hline 269 & & $88 \cdot 3$ & & $8 \cdot 8$ & 25.8 & & 66 \\
\hline 668 & & $34 \cdot 5$ & & & 8.0 & & 52 \\
\hline Planctomyces limnophilus DSM $3776^{\mathrm{T}}$ & & $57 \cdot 8$ & & $8 \cdot 8$ & $\mathrm{t}$ & & 53 \\
\hline 282 & & $77 \cdot 7$ & & $14 \cdot 6$ & & & 54 \\
\hline 287 & & $73 \cdot 6$ & & $4 \cdot 4$ & & & 54 \\
\hline 642 & & $80 \cdot 8$ & $0 \cdot 8$ & $8 \cdot 8$ & $0 \cdot 2$ & & 66 \\
\hline Pirellula staleyi DSM $6068^{\mathrm{T}}$ & & & & $0 \cdot 8$ & $50 \cdot 2$ & & 57 \\
\hline Pirellula marina DSM $3645^{\mathrm{T}}$ & & & & & $11 \cdot 3$ & & 56 \\
\hline 611 & & & & $5 \cdot 4$ & 28.6 & & 52 \\
\hline 302 & & $10 \cdot 7$ & & & $19 \cdot 2$ & & 52 \\
\hline 382 & & & & & $4 \cdot 7$ & & 57 \\
\hline 1 & & $19 \cdot 5$ & $15 \cdot 3$ & & $19 \cdot 6$ & & 55 \\
\hline 608 & & 1.8 & & & $7 \cdot 4$ & & 55 \\
\hline 140 & & $2 \cdot 0$ & & $0 \cdot 3$ & $4 \cdot 3$ & & 56 \\
\hline 384 & 1.5 & $7 \cdot 2$ & & $0 \cdot 3$ & $4 \cdot 6$ & & 58 \\
\hline 529 & & $2 \cdot 8$ & & & 5.6 & & 58 \\
\hline 158 & & & & & $14 \cdot 0$ & & 54 \\
\hline 139 & $2 \cdot 6$ & $1 \cdot 6$ & $1 \cdot 2$ & & 8.5 & & 57 \\
\hline 337 & & 21.9 & & & 14.9 & & 55 \\
\hline
\end{tabular}

* Result taken from Staley et al. (1992).

t, Trace amount $\left.[<0 \cdot 2 \mu \mathrm{mol} \text { (g dry weight })^{-1}\right]$.

strains contained high amounts of PUT and SPD. Pirellula staleyi contained high amounts of HSPD as the only predominant polyamine. The amount of polyamines was relatively small and mainly composed of HSPD and PUT in cells of Pirellula marina and related strain clusters; some strains possessed small amounts of CAD and DAP. Whether or not the presence of a more diverse pattern of polyamines in these strains is a reflection of their phylogenetic diversity needs to be tested by including more strains from the same phylogenetic cluster in the polyamine studies.

\section{Base composition of DNA}

The $\mathrm{G}+\mathrm{C}$ content of the type strains of the three described Planctomyces species investigated in this study were within a narrow margin of 51-56 mol \% (Table 3). Strains 282 and 287, which are phylogenetically related to and share the same polyamine composition as Planctomyces limnophilus DSM 3776 have a very similar DNA G $+\mathrm{C}$ content $(54 \mathrm{~mol} \%$ ). On the other hand, strain 642 which, phylogenetically, clusters remotely with the type strain of Planctomyces limnophilus has a significantly higher DNA $\mathrm{G}+\mathrm{C}$ content of $66 \mathrm{~mol} \%$. Planctomyces brasiliensis has a DNA $\mathrm{G}+\mathrm{C}$ content of $56 \mathrm{~mol} \%$. This value is different from those of strains that represent individual branches of a neighbouring cluster, i.e. strain 664 (52 $\mathrm{mol} \%)$ and strain $269(66 \mathrm{~mol} \%)$. The latter two strains also exhibit different polyamine patterns.

The DNA $\mathrm{G}+\mathrm{C}$ values of type strains of the two Pirellula species as well as those of the majority of Pirellula-related strains are very similar (54-58 $\mathrm{mol} \%$ ). Exceptions are the moderately related strains 611 and 302 ; both strains have a $\mathrm{G}+\mathrm{C}$ value of $52 \mathrm{~mol} \%$ and exhibit a unique polyamine pattern within the Pirellula cluster.

The DNA base ratio of strains related to $G$. obscuriglobus and I. pallida are about $6 \%$ higher than those of the type strains of these two species which 
have been reported by Staley et al. (1992). These differences may be due to methods used, as reported frequently in the literature. Nevertheless, the $\mathrm{G}+\mathrm{C}$ contents of members of these two genera are significantly higher than those of members of Planctomyces and Pirellula, a finding that supports their phylogenetic and chemotaxonomic distinctness. As mentioned above, members of Isosphaera differ markedly from the other strains studied in that their $\mathrm{G}+\mathrm{C}$ content of the gene(s) encoding $16 \mathrm{~S}$ rRNA is higher.

In conclusion, phylogenetic analysis of novel strains indicates the dramatic diversity contained within the order Planctomycetales. This phylogenetic diversity is confirmed by polyamine composition, the base ratio of DNA and, at least for I. pallida and related strains, the base ratio of rRNA. At the genomic and epigenomic level, the diversity of strains of novel planctomycete lineages is as high as that of described planctomycete genera. These novel strain clusters should be subjected to thorough polyphasic taxonomic analyses in order to determine whether they could be described as novel taxa.

\section{ACKNOWLEDGEMENTS}

The work was supported by grants from the Deutsche Forschungsgemeinschaft (Schl 1-1/2 and Sta 12-1/2). S.M. is grateful to the Deutscher Akademischer Austauschdienst for a long-term fellowship. We thank Jim Staley for kindly providing us with three planctomycete strains from Hawaii.

\section{REFERENCES}

Altenburger, P., Kämpfer, P., Akimov, V. N., Lubitz, W. \& Busse, H.-J. (1997). Polyamine distribution in actinomycetes with group B peptidoglycan and species of the genera Brevibacterium, Corynebacterium, and Tsukamurella. Int J Syst Bacteriol 47, 270-277.

Auling, G. (1992). Polyamines, biomarker for taxonomy and ecology of phytopathogenic and other bacteria belonging to the Proteobacteria. Belg J Bot 125, 203-209.

Auling, G., Busse, H.-J., Pilz, F., Webb, L., Kneifel, H. \& Claus, D. (1991). Rapid differentiation, by polyamine analysis, of Xanthomonas strains from phytopathogenic pseudomonads and other members of the class Proteobacteria interacting with plants. Int J Syst Bacteriol 41, 223-228.

Bomar, D., Giovannoni, S. \& Stackebrandt, E. (1988). A unique eubacterial 5S rRNA in members of the order Planctomycetales. $J$ Mol Evol 27, 121-125.

Brosius, J., Palmer, M. L., Kennedy, P. J. \& Noller, H. F. (1978). Complete nucleotide sequence of the $16 \mathrm{~S}$ ribosomal RNA gene from Escherichia coli. Proc Natl Acad Sci USA 75, 4801-4805.

Busse, H.-J. \& Auling, G. (1988). Polyamine patterns as a chemotaxonomic marker within the Proteobacteria. Syst Appl Microbiol 11, 1-8.

Cohen-Bazire, G., Sistrom, W. R. \& Stanier, R. Y. (1957). Kinetic studies of pigment synthesis by non-sulphur purple bacteria. $J$ Cell Comp Physiol 49, 25-68.

Felsenstein, J. (1993). PHYLIP (phylogenetic inference package) version 3.5.1. Department of Genetics, University of Washington, Seattle, WA, USA.
Franzmann, P. D. \& Skerman, V. B. D. (1984). Gemmata obscuriglobus, a new genus and species of the budding bacteria. Antonie Leeuwenhoek 50, 261-268.

Fuerst, J. A., Hawkins, J. A., Holmes, A., Sly, L. I., Moore, C. J. \& Stackebrandt, E. (1993). Porphyrobacter neustonensis gen. nov., sp. nov., an aerobic bacteriochlorophyll-synthesizing budding bacterium from fresh water. Int $J$ Syst Bacteriol 43, 125-134.

Giovannoni, S. J., Schabtach, E. \& Castenholz, R. W. (1987). Isosphaera pallida gen. nov., comb. nov., a gliding, budding eubacterium from hot springs. Arch Microbiol 147, 276-284.

Hamana, K. \& Matsuzaki, S. (1993). Polyamine distribution patterns serve as a phenotypic marker in the chemotaxonomy of the Proteobacteria. Can J Microbiol 39, 304-310.

Jukes, T. H. \& Cantor, C.R. (1969). Evolution of protein molecules. In Mammalian Protein Metabolism, pp. 21-132. Edited by $H$. N. Munro. New York: Academic Press.

König, H., Schlesner, H. \& Hirsch, P. (1984). Cell wall studies on budding bacteria of the Planctomyces/Pasteuria group and on a Prosthecomicrobium sp. Arch Microbiol 138, 200-205.

Liesack, W. \& Stackebrandt, E. (1989). Evidence for unlinked rrn operons in the planctomycete Pirellula marina. J Bacteriol 171, 5025-5030.

Liesack, W., König, H., Schlesner, H. \& Hirsch, P. (1986). Chemical composition of the peptidoglycan-free envelopes of budding bacteria of the Pirella/Planctomyces group. Arch Microbiol 145, 361-366.

Liesack, W., Söller, R., Stewart, T., Haas, H., Giovannoni, S. \& Stackebrandt, E. (1992). The influence of tachytelically evolving sequences on the topology of phylogenetic trees - intrafamily relationships and the phylogenetic position of Planctomycetaceae as revealed by comparative analysis of $16 \mathrm{~S}$ ribosomal RNA sequences. Syst Appl Microbiol 15, 357-362.

Lyman, J. \& Fleming, R. H. (1940). Composition of sea water. $J$ Mar Res 3, 134-146.

Marmur, J. (1961). A procedure for the isolation of deoxyribonucleic acid from microorganisms. $J$ Mol Biol 3, 208-218.

Mesbah, M., Premachandran, U. \& Whitman, W. B. (1989). Precise measurement of the $\mathrm{G}+\mathrm{C}$ content of deoxyribonucleic acid by high-performance liquid chromatography. Int $J$ Syst Bacteriol 39, 159-167.

Munro, G. F., Hercules, K., Morgan, J. \& Sauerbier, W. (1972). Dependence of the putrescine content of Escherichia coli on the osmotic strength of the medium. J Biol Chem 247, 1272-1280.

Rainey, F. A., Ward-Rainey, N., Kroppenstedt, R. M. \& Stackebrandt, E. (1996a). The genus Nocardiopsis represents a phylogenetically coherent taxon and a distinct actinomycete lineage: proposal of Nocardiopsaceae fam. nov. Int J Syst Bacteriol 46, 1088-1092.

Rainey, F. A., Ward-Rainey, N., Janssen, P. H., Hippe, H. \& Stackebrandt, E. (1996b). Clostridium paradoxum DSM $7308^{\mathrm{T}}$ contains multiple 16S rRNA genes with heterogeneous intervening sequences. Microbiology 142, 2087-2095.

Scherer, P. \& Kneifel, H. (1983). Distribution of polyamines in methanogenic bacteria. J Bacteriol 154, 1315-1322.

Schlesner, H. (1986). Pirella marina sp. nov., a budding, peptidoglycan-less bacterium from brackish water. Syst Appl Microbiol 8, 177-180.

Schlesner, H. (1994). The development of media suitable for the microorganisms morphologically resembling Planctomyces ssp., Pirellula ssp., and other Planctomycetales from various aquatic habitats using dilute media. Syst Appl Microbiol 17, 135-145. 
Schlesner, H. \& Hirsch, P. (1984). Assignment of ATCC 27377 to Pirella gen. nov. as Pirella staleyi comb. nov. Int $J$ Syst Bacteriol 34, 492-495.

Schlesner, H. \& Stackebrandt, E. (1986). Assignment of the genera Planctomyces and Pirella to. a new family Planctomycetaceae fam. nov. and description of the order Planctomycetales ord. nov. Syst Appl Microbiol 8, 174-176.

Sittig, M. \& Schlesner, H. (1993). Chemotaxonomic investigations of various prosthecate and/or budding bacteria. Syst Appl Microbiol 16, 92-103.

Staley, J. T. (1968). Prosthecomicrobium and Ancalomicrobium: new prosthecate freshwater bacteria. J Bacteriol 95, 1921-1942.

Staley, J. T., Fuerst, J. A., Giovannoni, S. \& Schlesner, H. (1992). The order Planctomycetales and the genera Planctomyces, Pirellula, Gemmata, and Isosphera. In The Prokaryotes. A Handbook on the Biology of Bacteria Ecophysiology, Isolation, Identification, Applications, pp. 3710-3731. Edited by A. Balows, H. G. Trüper, M. Dworkin, W. Harder \& K. H. Schleifer. New York: Springer.
Ward, N., Rainey, F. A., Stackebrandt, E. \& Schlesner, H. (1995). Unravelling the extent of diversity within the order Planctomycetales. Appl Environ Microbiol 61, 2270-2275.

Ward-Rainey, N., Rainey, F. A., Wellington, E. M. H. \& Stackebrandt, E. (1996). Physical map of the genome of Planctomyces limnophilus, a representative of the phylogenetically distinct planctomycete lineage. $J$ Bacteriol 178, 1908-1913.

Woese, C. R. (1987). Bacterial evolution. Microbiol Rev 51, 221-271.

Yamamoto, S., Shinoda, S., Kawaguchi, M., Wakamutsu, K. \& Makita, M. (1983). Polyamine distribution in Vibrionaceae: norspermidine as a general constituent of Vibrio species. Can J Microbiol 29, 724-728.

Yamamoto, S., Yoshida, M., Nakao, N., Koyama, M., Hashimoto, Y. \& Shinoda, S. (1986). Variations of cellular polyamine compositions and contents of Vibrio species during growth with various $\mathrm{NaCl}$ concentrations. Chem Pharm Bull (Tokyo) 34, 3038-3042. 